\title{
ACQUISITIONS ON THE CABLE TELEVISION MARKET IN POLAND - CONDITIONS AND PERSPECTIVES
}

\author{
WIESŁAW M. MAZIARZ \\ University of Szczecin, Faculty of Management and Economics of Services, POLAND \\ e-mail: wieslaw.maziarz@wzieu.pl
}

\begin{tabular}{l|l}
$\begin{array}{l}\text { RECEIVED } \\
\text { ACCEPTED }\end{array}$ & $\begin{array}{l}6 \text { November } 2018 \\
\text { J December } 2018\end{array}$ \\
CLL & \\
& L22, L97 \\
KEYWIFICATION & \\
& cable television market, regulations of telecommunications market, acquisitions
\end{tabular}

ABSTRACT The aim of the article is to identify and analyze factors affecting the scope and scale of acquisitions on the cable television market in Poland. The article presents a research hypothesis: Conditions for the functioning of the cable television market in Poland determine the use of strategies to take over competitors as the basic route for the development of operators. The adopted goal and research hypothesis influenced the content of the article. Substantive considerations in the article began with defining the term of an acquisition. Next, the objective and subjective scope of the cable television market was discussed. The rest of the article refers to the specificity of the cable television market and its impact on the acquisition in this market area, with particular emphasis on the infrastructure character of the provision of services. The article ends with a discussion of the factors determining the scope and scale of acquisitions on the cable television market.

\section{Introduction}

The cable television market in Poland is characterized by a relatively large number of operators, the growing level of application of technologically advanced infrastructure solutions and a significant reduction in the prices of services provided. Market reality is not beneficial for operators, due to the need to conduct permanent infrastructure investments and falling revenues. An important problem for operators is also the fact that in conditions 
of strong competition they have problems with business development. In this situation, operators are forced to look for strategic solutions that will provide perspectives for expansion. A strategic development option, very often considered and used in the cable television market practice, is an acquisition of competitors. The aim of the article is to identify and analyze factors affecting the scope and scale of acquisitions on the cable television market in Poland. The article adopts the research hypothesis: Conditions for the functioning of the cable television market in Poland determine the use of strategies to take over competitors as the basic route for the development of operators.

\section{The concept of strategic aceulisitions}

Acquisitions are strategic forms that are permanent and irreversible. In the simplest terms, this term should "refer to such activities, which result in the loss of control over a company by one group of people on behalf of another group" (Czekaj, Dresler, 1998, p. 246). These activities can take various forms, of which as the most important should be considered:

- purchase of existing company shares,

- purchase of an enterprise or part of its assets,

- privatization,

- increasing the company's equity and taking up new shares leading to the acquisition of control.

Acquisitions can be divided depending on different criteria. In the most popular approach, the following forms can be distinguished (Strategor, 1999, pp. 211-219):

- horizontal acquisitions involving the merger of companies that are actual or potential competitors,

- vertical acquisitions are carried out by enterprises whose business profile is within a given economic chain,

- acquisitions of the nature of related diversification involving the creation of groups of enterprises belonging to various sectors but conducting business operations interrelated in a technical or commercial sense,

- conglomerate acquisitions involving the merger of enterprises present in sectors between which there are no links.

The reasons why business entities make decisions about using acquisition options are the result of strategic priorities adopted by each company. According to the generally accepted classification concept, the prerequisites for making decisions on acquisitions can be divided into four groups. They are presented in Table 1.

Table 1. Motives of buyers in the process of acquisition of enterprises

\begin{tabular}{cl}
\hline \multicolumn{1}{c}{ Groups of motives } & \multicolumn{1}{c}{ Specific motives } \\
\hline 1 & \multicolumn{1}{c}{2} \\
\hline Technical and organizational & Operational synergy including: \\
& economies of scale, \\
& complementarity of resources and skills, \\
& reduction of transaction costs, \\
& benefits of technical integration \\
\hline Market and marketing & Increased market share. \\
& Increased value added. \\
& Diversification of risk. \\
& Complementarity of products and markets. \\
& Eliminating competition. \\
& Diversification of activity \\
\hline
\end{tabular}




\begin{tabular}{ll}
\hline \multicolumn{1}{c}{1} & \multicolumn{1}{c}{2} \\
\hline Financial & Use of surplus funds. \\
& Tax benefits. \\
& Lowering the cost of capital. \\
& Underestimation of the value of the acquired company \\
\hline Managerial & Increase in prestige and power. \\
& Reducing the risk of management. \\
& Increased freedom of action \\
\hline
\end{tabular}

Source: Frąckowiak (1998), p. 23

The presented motives of acquisitions do not exhaust all conditions that may be the basis for the company's decision to purchase another business entity. It is necessary to supplement them with factors that may determine the application of acquisition strategies (Strategor, 1999, pp. 211-219):

- sectoral features, i.e. the degree of maturity of a given field and the strength of entry barriers,

- tactical reasons related to the neutralization of a competitor and the game against time.

An important factor influencing the practical application of market activities of the acquisition strategy is the company's previous experience in this area. Companies that have made acquisitions in the past will be more interested in repeating this operation.

\section{Cable television market in Poland}

The cable television market is one of the leading areas of the telecommunication market in Poland, affecting the functioning of the economy and giving citizens access to multimedia services. Revenues of this sector in 2017 reached the value of nearly PLN 4 billion. The interest in cable television services is evidenced by the dynamic growth in the number of operators in the cable television sector, which allowed for reaching the number of over 4.2 million subscribers in 2017, including (GUS, 2017):

- 3.4 million digital TV subscribers,

- 3.05 million subscribers to Internet access,

- 1.25 million subscribers to IPTV telephony.

As it can be seen from the list, a significant part of subscribers use two or even three service forms provided by cable TV operators. Particular attention should be paid to the relatively high level of subscribers' interest in access to the Internet in cable television networks. According to statistical data, the share of cable TV operators in the Internet access market reached about $19 \%$ and in the case of households, the level of penetration amounted to $37 \%$. It is worth noting that entities operating in the cable television sector are the most important providers of permanent Internet access, with a market share of approximately $45 \%$, as well as leaders in offering the highest bandwidth access connections. Nevertheless, in recent years, the growth rate of the number of subscribers using the services provided by cable TV operators is decreasing and is significantly different from the currently leading mobile services market. This shows that the cable television market in Poland is entering a phase of maturity. The structure of the cable television market in Poland is very diverse. Despite the fact that about 500 cable network operators operate on it, nearly $90 \%$ of the market belongs to the 6 largest companies. 


\section{Determinants of the functioning of the cable television market in the context of the use of acquisition strategyies}

The cable television market is particularly susceptible to acquisitions of business entities operating on it. This is a consequence of the infrastructure nature of the provision of services, which is characterized by the following features:

- a relatively long period of shaping the infrastructure and a long period of its use,

- technical indivisibility of the infrastructure,

- high capital intensity of the infrastructure,

- spatial and functional immobility of facilities included in the infrastructure.

The presented features of the infrastructural character of the provision of cable television services in a special way affect the decisions to implement acquisitions by operators. For an economic entity interested in taking over a competitor, the acquisition is an alternative to the implementation of an infrastructure investment from scratch. It creates the possibility of quickly acquiring infrastructure and immediate provision of services via it. However, in the event of a decision on the construction of telecommunications infrastructure, investors must take into account the very long period of implementation of investment projects. The infrastructural nature of operations also determines the behaviour of operators who for various reasons decide to exit the market. In practice, they have no other option of recovering capital frozen in infrastructure, but only selling it to another telecommunications entity.

An important issue affecting operators' preferences for acquisitions is the fact that in market practice, consolidation strategies are quite often the only opportunity for strategic development. This situation is a consequence of the lack of:

- the economic justification for the spatial duplication of the network,

- statutory solutions that would allow operators to use other operators' infrastructure existing in a given area.

Thus, there may be an actual monopoly in the provision of cable television services in certain areas of the country. In this situation, the possible acquisition gives clear market benefits.

Considering the problems of an acquisition on the cable television market, special attention should be paid to the fact that the business entity, by taking over the operator providing the service, acquires not only its infrastructure and staff but also its subscribers. This circumstance is a very important factor in the decision-making process for the purchase of a telecommunications operator.

Operators accepting the acquisition option in their development strategies also take into account the economic benefits associated with operating activities. Increasing the number of subscribers allows for obtaining economies of scale. It results from the fact that such factors as expenditures related to the purchase or creation of programs, expenditures on marketing activities as well as costs of personnel employment or maintenance of infrastructure are permanent. Therefore, as the number of subscribers increases, the average total costs are reduced. Theoretical discussions about the prerequisites and predispositions for the acquisition on the cable television market are confirmed by the market reality. The period of dynamic growth in the number of operators in the 90 s of the twentieth century was followed by the era of consolidation on the market, with the use of virtually exclusively acquisition strategies. Analyzing the course of this process, it can be concluded that the largest number of acquisitions in the history of the Polish economy took place in the cable television sector. This situation was a consequence of the very fragmented economic structure of the market and the relatively weak financial foundations of the operators. On the emerging market, operations were undertaken by municipal and communal companies, housing cooperatives and individual investors. After a short time, it turned out that most of them were unable to meet the financial challenges 
resulting from the expansion of infrastructure or acquiring content and became the subject of acquisitions. The Polish origin of cable television operators influenced the fact that the vast majority of acquisitions were carried out by operators with Polish capital. In practice, the only significant acquisition in this market area by an entity with foreign capital was the acquisition of the PTK network by the global cable TV provider UPC that used this strategy to overcome barriers to entry into the sector. It is worth noting that all the acquisitions carried out in this sector were friendly. This was due to the specificity of the cable television market in Poland, the strategic and financial situation of operators and the ownership structure of operators.

\section{Prospects for the use of acquisitions in market activities of cable television operators}

The considerations regarding the use of acquisitions on the cable television market indicate that there is a relatively strong interest among operators in consolidation solutions. It should be assumed that this trend will continue in the future. This is indicated by the strategic conditions of the sector, which in the future should strongly determine the strategic behaviour of operators active in this area. The most important determinants of the cable television market include:

- the maturity of the cable television sector,

- fragmentation of operators in the cable television sector,

- strong disproportions of the potential of cable television operators.

While presenting the cable television market in Poland, it was pointed out that this sector is entering a maturity phase characterized by saturation of the market with services, a small inflow of new subscribers, a growing intensity of competitive activities and a reduction in revenues. This is a difficult market situation for operators who can take the following strategic solutions under these circumstances:

- an offensive option, based on searching for opportunities to improve the market position,

- a defensive option, which consists in defending the market position,

- withdrawal from the market related to the sale of a business.

Cable TV operators choose one of these strategies.

The issue of the maturity of the cable television sector should be considered together with the issue of significant fragmentation of operators and a strong disproportion of potential in this market area. The existence on the market of about 500 operators, the largest of which has 1,435 thousand subscribers and the smallest only a few hundred, create extremely attractive conditions that actually force the implementation of a consolidation strategy. Not all aspects that may have a potential impact on the scale of using acquisitions on the cable television market have been so far included in the considerations. It is also worth paying attention to activities resulting from legal and regulatory conditions. The following should be considered particularly important when using the consolidation strategy:

- potential changes in regulations shaping the operating conditions of cable television operators,

- the position of antimonopoly authorities regarding the acquisition.

The change in the regulations regarding the access to the infrastructure of cable television operators may have a significant impact on the use of the acquisition strategy on the cable television market in Poland. The consultations undertaken in this matter by the President of UKE (the Office of Electronic Communications) relate to the largest cable television networks, which may be obliged to make owned infrastructure available to their competitors for a fee. Possible adoption of this solution will change the competition rules in the sector, reducing investment costs 
and giving subscribers the possibility to choose a service provider. It is difficult to unequivocally assess the impact of this regulation on the acquisition processes on the market. On the one hand, the ability to reach customers without having to bear the costs associated with investing in infrastructure may encourage smaller operators to continue on the market and, consequently, result in a lack of interest in the sale of activities. On the other hand, however, it is difficult to expect that a small business entity would be able to offer clients services on terms more favourable than a large operator, whose cost aspects stem from economies of scale resulting from a large number of subscribers. The only solution for small operators may be to offer niche services that will be able to meet the needs of a small group of clients. However, it is difficult to expect significant development prospects when adopting such a strategic option.

The position of antimonopoly authorities is another regulatory factor affecting acquisitions on the cable television market. Each acquisition decision must be analyzed by UOKiK (OCCP), which examines whether the given concentration will not restrict competition on the market. If the OCCP recognizes that after the acquisition, the operator will achieve a dominant position, i.e. exceed $40 \%$ of the market share, it may order to sell a part of the infrastructure or even block the transaction. A practical example of such activities were the actions of OCCP, which considered the application of the largest cable TV operator in Poland, UPC, regarding the acquisition of Multimedia Polska, the third largest entity in this market area in terms of the number of subscribers. As a result, UPC withdrew the application and the acquisition, estimated at approximately PLN 3 billion, did not materialize.

The cable television market is facing technological changes that operators will have to rise to. The biggest challenge for them will be the need to provide services that require high bandwidth telecommunications connections and meeting increased network traffic. Already, part of the cable television network is switching to fibre optic infrastructure, which will provide better transmission conditions and thus will give operators more opportunities in shaping service offers. Soon, having a fibre-optic network will become a prerequisite for effective competition. Not all operators will be able to meet the financial requirements of infrastructure modernization and the only option left will be selling the company.

So far, the subject of deliberations has been the problems related to acquisitions within the cable television sector. However, it is worth paying attention to the potential possibilities of conducting acquisitions by operators from outside the sector. This observation results from the fact that the cable TV sector is becoming too small which is visible for some companies, especially the market leader, UPC. After the failure of the acquisition of Multimedia Polska, the company is looking for a new development option. Analyzing the potential and the range of services provided by UPC, attention is drawn to the lack of access to mobile telephony. All the more so because the largest competitors in the sector, Vectra and Multimedia Polska, are virtual operators and provide mobile services to their subscribers, and UPC has had relevant cooperation agreements signed with Play mobile operator for some time now. Perhaps this indicates that UPC is not interested in providing mobile telephony services as a virtual operator but as an infrastructure operator. This would mean that the company is planning to acquire one of the mobile phone network operators active on the Polish market. The only mobile operator that can be taken into account is Play, whose owners are investment funds. A possible acquisition would have a value of PLN 10 billion and would give UPC a strong position on the Polish telecommunications market. The combination of the potentials of both companies would create a portfolio of convergent services attractive for subscribers and a possibility to compete with the largest operators on the market. 


\section{Conclusion}

The issues regarding acquisitions on the cable television market in Poland presented in the article point to high consolidation activity of the largest operators. This is the result of the impact of many factors, which in turn determine the business entities operating in this market area to adopt strategic behaviours that favour acquisitions. Such a situation will also take place in the future and it can be anticipated that the number of operators active on the cable television market will significantly decline. However, it is quite difficult to build scenarios and assign specific market roles to individual operators.

\section{References}

Czekaj, J., Dresler, Z. (1998). Zarządzanie finansami przedsiębiorstw. Podstawy teorii. Warszawa: Wydawnictwo Naukowe PWN.

Frąckowiak, W. (ed.) (1998). Fuzje i przejęcia przedsiębiorstw. Warszawa: PWE.

GUS (2017). Poczta i telekomunikacja - wyniki działalności w 2016 r. Warszawa.

Strategor (1999). Zarządzanie firmą. Strategie, struktury, decyzje, tożsamość. Warszawa: PWE.

UKE (2018). Raport o stanie rynku telekomunikacyjnego w Polsce. Warszawa.

Cite this article aS: Maziarz, W.M. (2018). Acquisitions on the cable television market in Poland - conditions and perspectives. European Journal of Service Management, 4 (28/1), 199-205. DOI: 10.18276/ejsm.2018.28/1-25. 